\title{
SATELLITE DETECTION OF WILDLAND FIRES IN SOUTH AMERICA
}

\author{
Benjamin Leonardo Alves White ${ }^{1}$ \\ ${ }^{1 *}$ Universidade Federal de Sergipe, Departamento de Ciências Biológicas, São Cristóvão, Sergipe, Brasil - benjmk@hotmail.com \\ Recebido para publicação: 25/06/2018 - Aceito para publicação: 27/12/2018
}

\begin{abstract}
Resumo
Deteç̧ão de queimadas e incêndios florestais através de satélite na América do Sul. O uso de satélites para detectar queimadas e incêndios florestais se iniciou na década de 1980. Desde então, as suas imagens são utilizadas para a rápida detecção de fogo em vegetação, determinação da área queimada e servindo de base para o desenvolvimento de estratégias voltadas para a prevenção aos incêndios florestais. Este estudo tem por objetivo realizar uma análise espaço-temporal dos focos de calor detectados pelo satélite AQUA (sensor MODIS), processados pelo INPE utilizando o algoritmo de detecção "Collection 5", em toda a América do Sul para os anos de 2003 a 2017. Um total de 4.953.769 focos de calor foram analisados e o Brasil foi o país com maior número de registros, enquanto que Paraguai foi o que apresentou maior incidência por área (densidade). $\mathrm{O}$ ano de 2004 foi o que apresentou maior número de focos de calor detectados, enquanto que 2013 o menor. Tendência linear significativa foi observada apenas em dois países: Peru e Chile, em ambos os casos indicando tendência de alta durante o período avaliado. O mês com maior registro de focos de calor na América do Sul foi setembro, enquanto que março o menor. Cada país apresentou peculiaridades relacionadas aos meses com maior e menor ocorrência de fogo em vegetação devido, principalmente, às diferenças nos seus períodos chuvosos. As variações anuais no número de focos de calor observadas neste estudo se devem, sobretudo, ao comportamento humano e às variações climáticas provocadas pelo El Nino e La Nina.

Palavras-chave: Focos de calor, sensoriamento remoto, ocorrência de fogo.
\end{abstract}

\begin{abstract}
The detection of wildland fires by satellites began in the 1980s. Since them, satellite images have been used as an early wildfire detection system, for estimate burnt area and for assist the development of strategies focused on wildfires prevention. This study aims to analyse, spatially and temporally, the hot spots detected by the AQUA satellite (MODIS sensor), processed by the INPE using the "Collection 5" detection algorithm, in all South America for the years 2003 to 2017. A total of 4,953,769 hot spots where analysed and Brazil had the highest hot spot incidence while Paraguay presented the highest hot spots occurrence per area (density). The year of 2004 had the highest number of hot spots detected, while 2013 the lowest. Significant linear trend was observed only in two countries: Peru and Chile, in both cases indicating an uptrend during the assessed period. The month with the highest fire activity in South America was September, the least May. Each country presented differences regarding the months with higher and lower hot spots detected, mainly due to different rainfall patterns. The annual changes in the wildland fire occurrence observed in this study are mostly due to human behaviour linked with climate variations caused by the El Niño and La Niña.

Keywords: Control burn, hot spots, remote sensing, wildfire, fire occurrence.
\end{abstract}

\section{INTRODUCTION}

Fire is an ancient technique used by farmers for clearing land, reduce pests, diseases, costs and other purposes. Nevertheless, wildland fires (non-structure fires that occur in vegetation and natural fuels including planned and unplanned fires) can represent a threat to the preservation of biodiversity. In fire sensitive ecosystems, such as Atlantic or Tropical Forests, wildland fires are responsible for major environmental impacts that can lead to extinction of rare and endemic species. Also, they leave the soil more susceptible to erosion while releasing large amounts of greenhouse gases (SOARES; BATISTA, 2007). Although there are some ecosystems fire dependent, such as Savannas and the Brazilian Cerrado, where species have adapted to living in fire-prone environments, the exclusion or increase in fire frequency can also have negative environmental impacts (WHITE; WHITE, 2016). Moreover, the smoke often causes problems for human health, especially respiratory complications and represents, in some locations, a public health issue.

The detection of wildland fires via satellite began in the 1980s. Images generated by thermal and infrared sensors installed in these satellites are sent to a control center where they are processed through detection algorithms (BATISTA, 2004; WANG et al., 2012). It is essential the use of efficient algorithms since, originally, the hot spot data generated by the thermal sensors does not mean, necessarily, a wildland fire, but that certain area has a high temperature. The AVHRR (advanced very high resolution radiometer) sensor, for instance, captures and records any temperature above $47^{\circ} \mathrm{C}$ and indicates it as being a hot spot (BATISTA, 2004). However, industry furnaces, steel mills or hot asphalt, for example, can reach temperatures above $47^{\circ} \mathrm{C}$. That is why the images

FLORESTA, Curitiba, PR, v. 49, n. 4, p. 851 - 858, out/dez 2019.

White, B. L. A. et.al.

ISSN eletrônico 1982-4688

851

DOI: $10.5380 /$ rf.v49 i4.60117 
generated by the satellite sensors need to pass through a good algorithm that excludes such data, generating a low number of false alarms.

On the other hand, omission errors are more common and is related to technical limitations of the currently used sensors. This usually occurs when the fire has a small front line. For polar orbiting satellites equipped with MODIS (Moderate Resolution Imaging Spectroradiometer) sensor, for example, the fire line needs to be greater than $30 \mathrm{~m}$ in length by $1 \mathrm{~m}$ in width (PEREIRA et al. 2012; INPE 2018). Additionally, fire detection may also be restricted when fires started and ended during the interval between the satellite passage; by the presence of dense clouds above the burning area; surface fire under closed canopy vegetation; and fire on mountainsides opposite to the satellite observation path (PEREIRA et al. 2012; INPE 2018). Therefore, the number of wildland fires recorded corresponds with only a part of the total number (BATISTA, 2004; WHITE; WHITE, 2016; WHITE, 2018).

An important study done by Giglio et al. (2016) validated the Collection 5 MODIS fire product using reference fire maps derived from more than 2500 high-resolution Advanced Spaceborne Thermal Emission and Reflection Radiometer (ASTER) images. The authors, concluded that the MODIS overall omission error using fires of all sizes, including fire as small as $4 \mathrm{~m}^{2}$ in extent, is $86,2 \%$, wile less than $10 \%$ for reference fires composed of 140 or more $30-\mathrm{m}$ ASTER fire pixels. According the same authors, the global commission error (false alarms) was $2.4 \%$ for the Collection 5 MODIS fire product. The false alarms were generated mostly in areas dominated by dense woody vegetation, when differential solar reflection and heating can sometimes lead to ambiguous classification of land surface pixels.

In Brazil, the Weather and Climate Studies Research Center (CPTEC) of the National Institute for Space Research (INPE) generates and provides on their website, open access to hot spots data recorded by different satellites and processed by algorithms that indicate wildland fire all over the South America continent. Although receiving images from various satellites in operation (NOAA-15, NOAA-18, NOAA-19, METOP-B, NASA, TERRA, AQUA, NPP-Suomi, GOES-13 and MSG-3), the "reference satellite" is used to compose a time series over the years and thus enable trend analysis focused on numbers for the same periods in regions of interest. From July/2002 until the present day, INPE uses as reference the data from the polar orbiting AQUA satellite equipped with a MODIS sensor. The data from the reference satellite allows analyzes of spatial and temporal trends, since it uses the same method and the same time of day to capture the images over the years (INPE, 2018). The INPE used until early 2018 the "Collection 5" algorithm to process the images generated by MODIS sensors. Currently, they are using the "Collection 6" algorithm (INPE, 2018).

Wildland fires occur only when the weather and, consequently, the vegetation is dry, and an ignition source is present (SOARES; BATISTA, 2007). Therefore, changes in the weather directly interfere in the wildland fire occurrence. Over the last three decades, global temperatures have increased by $\sim 0.2{ }^{\circ} \mathrm{C}$ per decade (HANSEN et al., 2010) causing more severe and widespread droughts leaving the vegetation drier and prone to burn. Climate change is responsible for an increase in the global fire occurrence and pyrogeographic shifts (JOLLY et al., 2015). New studies indicate that in the second half of this century wildfire potential will increase significantly in South America due to global warming (LIU et al., 2010; FLANNIGAN et al., 2013). This increase will require new methodologies for preventing fire disasters, also more investments, resources, equipment and labor for fire combat and recovery of damaged areas.

The exact scope of the wildland fire problem in South America is difficult to determine and can only be assessed by satellite data, since local fire statistics in many cases are incomplete or misleading (FAO, 2007). Therefore, this study aims to analyze the hot spots detected by the AQUA satellite, processed by INPE using the "Collection 5" algorithm, in all South America for the last 15 years (2003-2017). The information obtained with this study can be used to assist the development of public policy focused on wildfire prevention and nature conservancy considering the differences and peculiarities in the wildland fire occurrence in each country.

\section{METHODOLOGY}

\section{Characterization of the study area}

South America is the fourth major continent of the planet with an area of $17,840,000 \mathrm{~km}^{2}$. It is bordered on the west by the Pacific Ocean, on east by the Atlantic Ocean and on the northwest by the Darién watershed along the Colombia-Panama border. It includes twelve sovereign states - Argentina, Bolivia, Brazil, Chile, Colombia, Ecuador, Guyana, Paraguay, Peru, Suriname, Uruguay, and Venezuela - and two non-sovereign areas - French Guiana, a region of France, and the Falkland Islands, a British overseas Territory.

There is a wide range of climate conditions on the South America continent and the distribution of vegetation follows annual and seasonal precipitation patterns. Evergreen forest occurs where rainfall is abundant, but savannah, grassland, shrubland and drought deciduous forest become increasingly common as precipitation decreases (MENDONÇA; DANNI-OLIVEIRA, 2017). 
South America has the largest area of tropical forests in the world, the greatest amount of biodiversity, and a large reservoir of above and below ground carbon stock. The Guiana Shield (an area that includes all of Guyana, Suriname and French Guiana, and that extends from Colombia and Venezuela in the west to portions of Brazil in the east), in particular, is vastly diverse biologically, being one of the most important centers of species richness on the planet (GIRI; LONG, 2014).

Hot spot data and statistical analysis

Data of hot spots generated by the AQUA satellite and processed by the INPE using the "Collection 5" algorithm was downloaded from the INPE/CPTEC website for the period of 01/01/2003 to 31/12/2017. The data were categorized according to country, month and year in order to analyze trends and seasonal and spatial variations.

To determine the frequency of hot spots incidence, all counties were grouped according to the classification proposed by White and White (2016) into five groups based on their size divided by the number of hot spots detected by AQUA satellite during a period of one year (Table 1).

Table 1. Frequency of incidence of hot spots detected by AQUA satellite over one year. The classification follows White and White (2016).

Tabela 1. Classificação proposta por White e White (2016) indicando a frequência da incidência de focos de calor utilizando o satélite AQUA.

\begin{tabular}{cc}
\hline Frequency class & Number of hot spots detected per year \\
\hline Very Low & None or one hot spot for an area of $601 \mathrm{~km}^{2}$ or more. \\
Low & One hot spot for an area between $301-600 \mathrm{~km}^{2}$. \\
Average & One hot spot for an area between $151-300 \mathrm{~km}^{2}$. \\
High & One hot spot for an area between $76-150 \mathrm{~km}^{2}$. \\
Very High & One hot spot for an area of $75 \mathrm{~km}^{2}$ or less. \\
\hline
\end{tabular}

Tukey HDS test was used to check for significant differences between the mean number of hot spots detected per month in all South America countries. Linear regression was used to assess the expected growth or decline in the number of hotspots in the coming years for all countries. The significance level for all statistical analysis was $5 \%$.

\section{RESULTS}

\section{Spatial analysis}

A total of 4,953,769 hot spots where detected by the AQUA satellite in South America during the 15 years assessed. Brazil had the highest wildland fire occurrence, followed by Argentina, Bolivia, Paraguay, Venezuela, Colombia, Peru, Chile, Equator, Guyana, Uruguay, Suriname and French Guiana (Table 2).

Table 2. Number of hot spots detected by AQUA satellite in South America countries from 2003 to 2017.

Tabela 2. Número de focos de calor detectados nos países da América do Sul pelo satélite AQUA de 2003 a 2017.

\begin{tabular}{|c|c|c|c|c|c|c|c|c|c|c|c|c|c|c|}
\hline Year & $\mathrm{AR}$ & $\mathrm{BO}$ & $\mathrm{BR}$ & $\mathrm{CH}$ & $\mathrm{CO}$ & $\mathrm{EC}$ & FG & GY & PA & $\mathrm{PE}$ & SU & UR & VE & Total \\
\hline 2003 & 53,311 & 28,038 & 235,158 & 1,853 & 20,194 & 1,881 & 261 & 1,672 & 34,044 & 9,532 & 604 & 480 & 32,250 & 419,278 \\
\hline 2004 & 47,120 & 47,771 & 270,295 & 1,920 & 21,438 & 2,203 & 328 & 956 & 23,584 & 5,190 & 409 & 700 & 19,528 & 441,442 \\
\hline 2005 & 29,918 & 40,771 & 240,707 & 2,118 & 12,385 & 2,947 & 295 & 814 & 22,715 & 10,949 & 260 & 399 & 20,298 & 384,576 \\
\hline 2006 & 34,543 & 30,166 & 136,852 & 1,518 & 9,415 & 1,088 & 185 & 583 & 18,274 & 5,692 & 287 & 210 & 16,363 & 255,176 \\
\hline 2007 & 24,515 & 36,716 & 231,211 & 1,408 & 18,010 & 1,354 & 97 & 481 & 25,003 & 7,809 & 70 & 186 & 18,904 & 365,764 \\
\hline 2008 & 38,643 & 30,467 & 123,201 & 2,442 & 10,410 & 906 & 242 & 449 & 14,783 & 5,927 & 274 & 445 & 17,071 & 245,260 \\
\hline 2009 & 41,595 & 20,581 & 123,120 & 3,087 & 12,644 & 3,366 & 361 & 1,188 & 16,101 & 7,700 & 680 & 455 & 18,505 & 249,383 \\
\hline 2010 & 24,739 & 66,195 & 249,198 & 2,419 & 12,155 & 851 & 157 & 927 & 16,740 & 10,039 & 288 & 519 & 23,470 & 407,697 \\
\hline 2011 & 35,683 & 28,041 & 132,893 & 2,421 & 8,406 & 2,423 & 155 & 703 & 18,975 & 7,384 & 215 & 479 & 10,403 & 248,181 \\
\hline 2012 & 29,551 & 20,049 & 193,600 & 2,671 & 11,345 & 1,934 & 319 & 995 & 16,310 & 11,590 & 545 & 439 & 12,378 & 301,726 \\
\hline 2013 & 32,599 & 16,073 & 115,046 & 2,454 & 11,175 & 1,707 & 93 & 693 & 22,333 & 7,730 & 207 & 448 & 20,330 & 230,888 \\
\hline 2014 & 19,664 & 16,748 & 183,424 & 2,429 & 13,679 & 1,179 & 179 & 1,023 & 14,639 & 8,432 & 369 & 454 & 20,966 & 283,185 \\
\hline 2015 & 27,610 & 22,350 & 236,066 & 3,612 & 12,495 & 1,096 & 275 & 1,584 & 14,371 & 11,565 & 529 & 1,504 & 18,046 & 351,103 \\
\hline 2016 & 32,087 & 37,308 & 188,044 & 2,713 & 15,952 & 3,143 & 385 & 1,216 & 22,981 & 13,134 & 624 & 489 & 20,262 & 338,338 \\
\hline 2017 & 40,258 & 34,928 & 275,120 & 6,793 & 12,415 & 1,955 & 166 & 937 & 30,205 & 11,189 & 338 & 537 & 16,931 & 431,772 \\
\hline $\begin{array}{c}\text { Annual } \\
\text { mean }\end{array}$ & 32,558 & 28,407 & 181,764 & 2,407 & 13,509 & 1,765 & 228 & 924 & 18,855 & 6,929 & 354 & 501 & 17,442 & 330,251 \\
\hline Total (\%) & 10.33 & 9.61 & 59.23 & 0.80 & 4.08 & 0.57 & 0.07 & 0.29 & 6.28 & 2.70 & 0.12 & 0.16 & 5.77 & 100 \\
\hline
\end{tabular}

FLORESTA, Curitiba, PR, v. 49, n. 4, p. 851 - 858, out/dez 2019.

White, B. L. A. et.al.

ISSN eletrônico 1982-4688

DOI: $10.5380 /$ rf.v49 i4.60117 
Taking into consideration the size of the South America countries, Paraguay was the nation with the highest hot spot occurrence per area, with an annual mean of one hot spot detected for each $20 \mathrm{~km}^{2}$, followed by Bolivia, Brazil, Venezuela, Argentina, Colombia, Peru, Equator, Guyana, Chile, Uruguay, French Guiana and Suriname. According to the classification proposed by White and White (2016), Paraguay, Bolivia, Brazil and Venezuela can be classified as countries with "Very High" wildland fire incidence (with 1 hot spot detected by AQUA satellite per year for each $75 \mathrm{~km}^{2}$ or less). Using the same classification criteria, Argentina, Colombia and Peru can be categorized in the "High" wildland fire incidence category, while Equator, Guyana, and Chile in the "Medium" group. Uruguay, French Guiana and Suriname are ranked in the "Low" category (Table 3).

Table 3. List of South American countries and their area; mean annual number of hot spots; area divided by the mean annual number hot spot (HS density); and hot spot frequency of incidence.

Tabela 3. Lista dos países da América do Sul e suas respectivas áreas; média anual de focos de calor; área dividida pela média anual de focos de calor (densidade); e, frequência de incidência.

\begin{tabular}{ccccc}
\hline Country & Size $\left(\mathrm{km}^{2}\right)$ & $\begin{array}{c}\text { Mean annual number of } \\
\text { hot spots }(\mathrm{HS})\end{array}$ & $\begin{array}{c}\text { Mean annual hot spots density } \\
\left(\mathrm{km}^{2} / \mathrm{HS}\right)\end{array}$ & Frequency of incidence* \\
\hline Paraguay & 406,750 & 20,737 & 20 & Very High \\
Bolivia & $1,098,580$ & 31,747 & 35 & Very High \\
Brazil & $8,511,965$ & 195,596 & 44 & Very High \\
Venezuela & 912,050 & 19,047 & 48 & Very High \\
Argentina & $2,766,890$ & 34,122 & 81 & High \\
Colombia & $1,138,910$ & 13,475 & 85 & High \\
Peru & $1,285,220$ & 8,924 & 144 & Medium \\
Ecuador & 283,560 & 1,869 & 152 & Medium \\
Guyana & 214,999 & 948 & 227 & Medium \\
Chile & 756,950 & 2,657 & 285 & Low \\
Uruguay & 176,220 & 516 & 341 & Low \\
French Guiana & 91,000 & 233 & 391 & Low \\
Suriname & 163,270 & 380 & 430 & \\
\hline
\end{tabular}

* According White and White (2016) classification.

Yearly temporal analysis

Considering all hot spots detected in the South America continent in the last 15 years, 2004 was the year with the highest detection, while 2013 the lowest. No significant trend was detected considering all the continent $\left(r^{2}=0.03 ; p=0.81\right)$ (Figure 1). However, examining the countries individually, significant uptrend was detected in Peru $\left(r^{2}=0.30 ; p=0.03\right)$ and Chile $\left(r^{2}=0.45 ; p<0.01\right)$ (Figure 2).

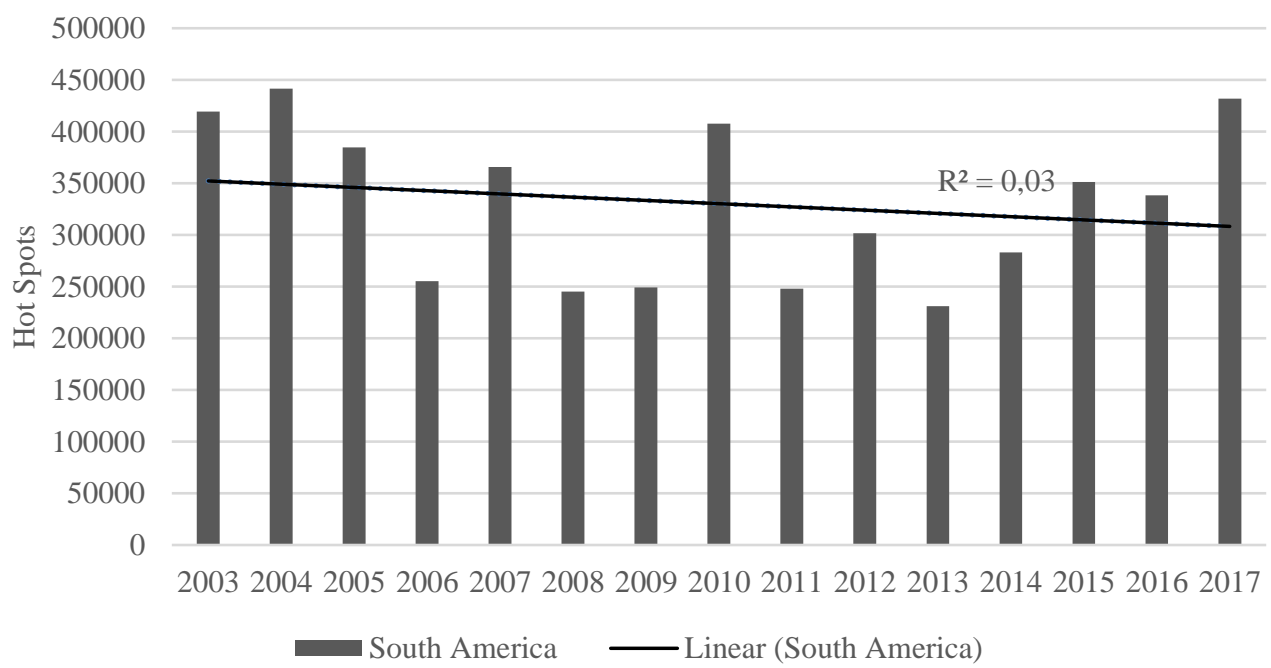

Figure 1. Yearly number of hot spots detected by AQUA satellite in South America continent between 2003 and 2017. The regression line indicates no significant linear trend.

Figura 1. Número anual de focos de calor detectados pelo satélite AQUA no continente Sul Americano de 2003 a 2017. A linha de regressão indica a ausência de tendência significativa. 


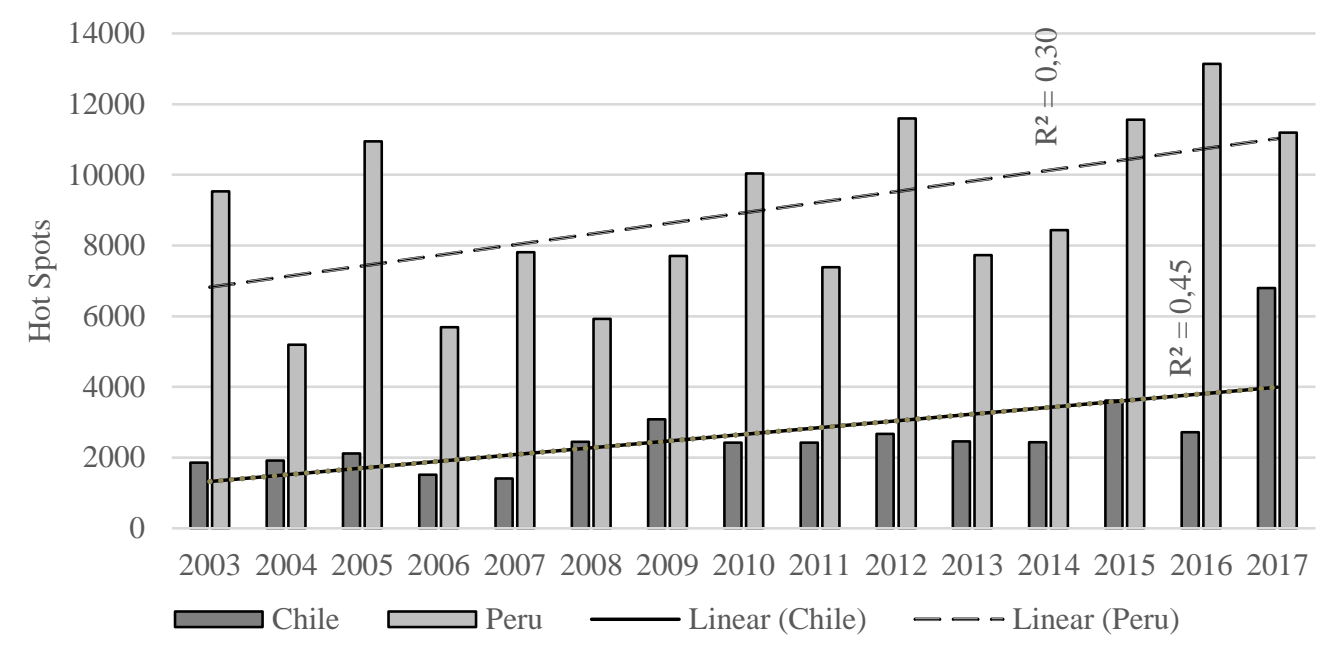

Figure 2. Yearly number of hot spots detected by AQUA satellite in Chile and Peru between 2003 and 2017. The regression lines indicate significant linear upward trend in both countries.

Figura 2. Número anual de focos de calor detectados pelo satélite AQUA no Chile e no Peru de 2003 a 2017. As linhas de regressão indicam tendência significativa de alta em ambos os países.

Monthly temporal analysis

The month with the highest record of hot spots in South America was September, followed by August, October, November, July, December, March, January, February, June, April and May.

Considering each country individually, Brazil, Bolivia, Paraguay and Peru had their highest wildland fire occurrence in the month of September. In French Guiana, Guyana and Suriname the month with highest hot spot occurrence was October. In Argentina and Uruguay was a little earlier, in August. In Chile and Venezuela, March. Colombia presented higher hot spots incidence in February and Equator in November (Table 4).

Table 4. Monthly mean numbers of hot spots detected by AQUA satellite in all South America (SA) countries between 2003 and 2017.

Tabela 4. Média mensal do número de focos de calor registrados pelo satélite AQUA nos países da América do Sul de 2003 a 2017.

\begin{tabular}{|c|c|c|c|c|c|c|c|c|c|c|c|c|}
\hline Country & Jan. & Feb. & Mar. & Apr. & May. & Jun. & Jul. & Aug. & Sept. & Oct. & Nov. & Dec. \\
\hline AR & $1,593^{\mathrm{C}, \mathrm{D}}$ & $1,280^{\mathrm{C}, \mathrm{D}}$ & $1,331^{\mathrm{C}, \mathrm{D}}$ & $991^{\mathrm{D}}$ & $519^{D}$ & $1,003^{\mathrm{D}}$ & $3,208^{\mathrm{B}, \mathrm{C}}$ & $8,704^{A}$ & $8,570^{\mathrm{A}}$ & $3,874^{\mathrm{B}}$ & $1,992^{\mathrm{B}, \mathrm{C}, \mathrm{D}}$ & $1,056^{\mathrm{D}}$ \\
\hline $\mathrm{BO}$ & $164^{\mathrm{C}}$ & $98^{\mathrm{C}}$ & $110^{\mathrm{C}}$ & $183^{\mathrm{C}}$ & $309^{\mathrm{C}}$ & $682^{\mathrm{C}}$ & $2,267^{\mathrm{C}}$ & $8,794^{\mathrm{A}, \mathrm{B}}$ & $11,672^{A}$ & $5,779^{\mathrm{B}}$ & $1,350^{\mathrm{C}}$ & $340^{\mathrm{C}}$ \\
\hline BR & $3,223^{\mathrm{D}}$ & $1,824^{\mathrm{D}}$ & $2,035^{\mathrm{D}}$ & $1,722^{\mathrm{D}}$ & $2,419^{\mathrm{D}}$ & $5,379^{\mathrm{D}}$ & $12,221^{\mathrm{C}, \mathrm{D}}$ & $40,347^{\mathrm{B}}$ & $63,586^{A}$ & $34,600^{\mathrm{B}}$ & $18,371^{\mathrm{C}}$ & $9,865^{\mathrm{C}, \mathrm{D}}$ \\
\hline $\mathrm{CH}$ & $454^{\mathrm{A}, \mathrm{B}}$ & $219^{\mathrm{B}, \mathrm{C}}$ & $744^{A}$ & $523^{\mathrm{A}, \mathrm{B}}$ & $224^{\mathrm{B}, \mathrm{C}}$ & $62^{\mathrm{C}}$ & $25^{\mathrm{C}}$ & $37^{\mathrm{C}}$ & $73^{C}$ & $87^{\mathrm{C}}$ & $80^{\mathrm{C}}$ & $129^{\mathrm{C}}$ \\
\hline $\mathrm{CO}$ & $2,520^{\mathrm{B}}$ & $3,919^{A}$ & $3,303^{\mathrm{A}, \mathrm{B}}$ & $574^{\mathrm{C}}$ & $141^{\mathrm{C}}$ & $141^{\mathrm{C}}$ & $294^{\mathrm{C}}$ & $526^{\mathrm{C}}$ & $512^{\mathrm{C}}$ & $406^{\mathrm{C}}$ & $433^{\mathrm{C}}$ & $705^{\mathrm{C}}$ \\
\hline EC & $54^{\mathrm{D}}$ & $32^{\mathrm{D}}$ & $18^{\mathrm{D}}$ & $21^{\mathrm{D}}$ & $14^{\mathrm{D}}$ & $20^{\mathrm{D}}$ & $32^{\mathrm{D}}$ & $107^{\mathrm{C}, \mathrm{D}}$ & $193^{\mathrm{B}, \mathrm{C}, \mathrm{D}}$ & $276^{\mathrm{B}, \mathrm{C}}$ & $766^{A}$ & $337^{\mathrm{B}}$ \\
\hline FG & $3^{C}$ & $1^{\mathrm{C}}$ & $2^{\mathrm{C}}$ & $2^{C}$ & $1^{\mathrm{C}}$ & $0^{\mathrm{C}}$ & $0^{\mathrm{C}}$ & $4^{C}$ & $40^{\mathrm{B}}$ & $125^{A}$ & $50^{\mathrm{B}}$ & $6^{\mathrm{C}}$ \\
\hline GY & $89^{\mathrm{B}, \mathrm{C}, \mathrm{D}, \mathrm{E}}$ & $65^{\mathrm{B}, \mathrm{C}, \mathrm{D}, \mathrm{E}}$ & $110^{\mathrm{B}, \mathrm{C}}$ & $106^{\mathrm{B}, \mathrm{C}, \mathrm{D}}$ & $18^{\mathrm{D}, \mathrm{E}}$ & $4^{\mathrm{E}}$ & $5^{\mathrm{E}}$ & $21^{\mathrm{C}, \mathrm{D}, \mathrm{E}}$ & $101^{\mathrm{B}, \mathrm{C}, \mathrm{D}}$ & $225^{A}$ & $134^{\mathrm{B}}$ & $69^{\mathrm{B}, \mathrm{C}, \mathrm{D}, \mathrm{E}}$ \\
\hline PA & $751^{\mathrm{B}, \mathrm{C}}$ & $828^{\mathrm{B}, \mathrm{C}}$ & $1,002^{\mathrm{B}, \mathrm{C}}$ & $697^{\mathrm{B}, \mathrm{C}}$ & $281^{\mathrm{C}}$ & $506^{\mathrm{C}}$ & $1,707^{\mathrm{B}, \mathrm{C}}$ & $5,331^{\mathrm{A}}$ & $\mathbf{5 , 8 2 8 ^ { A }}$ & $2,267^{\mathrm{B}}$ & $1,039^{\mathrm{B}, \mathrm{C}}$ & $499^{C}$ \\
\hline PE & $173^{\mathrm{D}, \mathrm{E}}$ & $111^{\mathrm{D}, \mathrm{E}}$ & $46^{\mathrm{E}}$ & $56^{\mathrm{E}}$ & $87^{\mathrm{D}, \mathrm{E}}$ & $178^{\mathrm{D}, \mathrm{E}}$ & $625^{\mathrm{C}, \mathrm{D}}$ & $2,529^{\mathrm{B}}$ & $3,408^{\mathrm{A}}$ & $1,120^{\mathrm{C}}$ & $452^{\mathrm{D}, \mathrm{E}}$ & $139^{\mathrm{D}, \mathrm{E}}$ \\
\hline SU & $12^{\mathrm{D}}$ & $9^{\mathrm{D}}$ & $22^{\mathrm{C}, \mathrm{D}}$ & $15^{\mathrm{D}}$ & $4^{\mathrm{D}}$ & $0^{\mathrm{D}}$ & $1^{\mathrm{D}}$ & $9^{\mathrm{D}}$ & $58^{\mathrm{B}, \mathrm{C}}$ & $164^{\mathrm{A}}$ & $70^{\mathrm{B}}$ & $16^{\mathrm{C}, \mathrm{D}}$ \\
\hline UR & $42^{\mathrm{A}, \mathrm{B}}$ & $15^{\mathrm{B}}$ & $30^{\mathrm{A}, \mathrm{B}}$ & $44^{\mathrm{A}, \mathrm{B}}$ & $39^{\mathrm{A}, \mathrm{B}}$ & $41^{\mathrm{A}, \mathrm{B}}$ & $51^{\mathrm{A}, \mathrm{B}}$ & $76^{A}$ & $64^{\mathrm{A}, \mathrm{B}}$ & $33^{\mathrm{A}, \mathrm{B}}$ & $40^{\mathrm{A}, \mathrm{B}}$ & $38^{\mathrm{A}, \mathrm{B}}$ \\
\hline VE & $3,336^{\mathrm{B}}$ & $3,852^{\mathrm{B}}$ & $5,351^{A}$ & $2,622^{\mathrm{B}}$ & $737^{\mathrm{C}}$ & $175^{\mathrm{C}}$ & $157^{\mathrm{C}}$ & $238^{\mathrm{C}}$ & $359^{C}$ & $445^{\mathrm{C}}$ & $589^{C}$ & $1,185^{\mathrm{C}}$ \\
\hline SA & $12,414^{\mathrm{D}, \mathrm{E}, \mathrm{F}}$ & $12,254^{\mathrm{D}, \mathrm{E}, \mathrm{F}}$ & $14,105^{\mathrm{D}, \mathrm{E}, \mathrm{F}}$ & $7,557^{\mathrm{E}, \mathrm{F}}$ & $4,793^{\mathrm{F}}$ & $8,195^{\mathrm{E}, \mathrm{F}}$ & $20,594^{\mathrm{D}, \mathrm{E}}$ & $66,724^{\mathrm{B}}$ & $94,464^{A}$ & $49,401^{\mathrm{C}}$ & $25,367^{\mathrm{D}}$ & $14,385^{\mathrm{D}, \mathrm{E}, \mathrm{F}}$ \\
\hline
\end{tabular}

Note: Values followed by the same letter do not differ statistically from each other at 5\% significance according the Tukey HDS test.

\section{DISCUSSION}

The variation in the number and density of hot spots detected throughout the South America countries is due to the differences on cultural aspects of the population and on environmental factors that influence fire 
propagation such as weather conditions, vegetation and topography (SOARES; BATISTA, 2007; WHITE; WHITE, 2016). In a similar study done in the state of Amazonas, Brazil, for example, White (2018) concluded that the municipalities with the highest number of hot spots detected were the ones that presented the largest deforested, pasture and agricultural areas; and were the ones with the lowest mean annual rainfall. According to the same author, the cultural practice of using fire for clearing forests, pastures and agricultural areas during the driest months of the year and, most of the time, without using fire safety measurements, is responsible for a large number of high intensity wildfires that are easily detected by satellite sensors. Land occupation and use, demographic density, topography (elevation, slope and aspect) and weather parameters such as rainfall, temperature and air relative humidity are the variables most used in the literature for assessing wildfire risk (SOARES; BATISTA, 2007).

The main ecosystem affected by fire in South America is the Amazon tropical rainforest (NOLASCO; SANHUEZA, 2011). The conversion of the Amazon forest into agricultural and pasture areas is responsible for a high number of fire events in Bolivia, Brazil, Venezuela and Colombia. Savannas and shrubland are also highly affected by wildland fires in Brazilan Cerrado, Bolivia, Colombia, and Venezuela. Such fires account for $13 \%$ of the total area burned in South America (NOLASCO; SANHUEZA, 2011). Forestry areas with pine and eucalyptus also are constantly affected by wildfires, mostly in Brazil, Chile and Argentina (GOLDAMMER, 2001).

According to Nolasco and Sanhueza (2011), the forests in the south of Brazil and east of Paraguay almost disappeared in the last decades due to expansion of soybean cultivation. The process of forest conversion to agricultural areas through the use of fire and the subsequent continuous use of controlled burns for land management led Paraguay to be the country with the highest number of hot spots detected per area during the years assessed in this study.

The low incidence of wildland fires in Guyana, Uruguay, Suriname and French Guiana are mostly linked to the natural vegetation and low rates of deforestation and land-use change. Fires, generally, do not affect wellconserved tropical forests (FAO, 2007; SOARES; BATISTA, 2007). In such ecosystems, the incidence of solar radiation in the understory is reduced by the canopy cover and the air humidity is high due to the evapotranspiration of the trees. Consequently, the moisture content of the fuel load is usually high, making it difficult for a fire to ignite and propagate (WHITE; SILVA, 2018).

In Uruguay and the south of Brazil, due to the vastness of grasslands, wildland fires are not a serious problem (GOLDAMMER, 2001). Even though fires can easily propagate in grasslands during the dry season, they usually have a low intensity due to the small amount of fuel load available for burning. While in an eucalyptus plantation the amount of available superficial fuel load can reach more than 30 tons per hectare, in grasslands this amount usually does not exceed 6 t/ha (WHITE et al., 2014). Low intensity fires may not be detected by MODIS sensors (INPE, 2018).

In a similar study, but using AVHRR images from the NOAA satellite, Bella et al. (2006) detected a total of 2,073,425 wildland fires for the period of August 1999-April 2001 in Argentina, Brazil, Paraguay, Uruguay, Bolivia and Chile. According the same authors, Brazil and Argentina had the highest numbers, $84 \%$ of the total fires (63\% and $21 \%$, respectively), followed by Bolivia 6\%, Paraguay $6 \%$ and Chile $4 \%$. Regarding the burnt area, Nolasco and Sanhueza (2011) concluded that the mean annual area burned in all South America continent is equivalent to the size of Venezuela.

The interannual changes in South America wildland fire occurrence found in this study can be linked with climate variations caused by El Niño and La Nina. The El Niño alters rainfall patterns and intensifies drought in some South America regions leaving the vegetation dryer and more prone to burn. On the other hand, La Nina causes an increase in rainfall in some South America regions.

The El Niño events during the years of 2004, 2015 and 2016 are likely responsible for an increase in the number of hot spots detected during those years. The La Nina occurrences in 2008 and 2011 are likely responsible for the reduction of wildland fires during these years.

The non-increase trend in the number of hot spots detected by the AQUA satellite over the last 15 years in the South America continent contradicts the expectation of higher fire occurrence due to global warming (JOLLY et al., 2015). Analyses of other factors that influence wildland fire occurrence, such as changes in land use, should be done in order to justify the found results. Also, is important to take into consideration that climate trend analysis should, preferably, apply data series longer than 30 years, since normal climate is usually defined for three decades. The 15 year period used in this study (since the AQUA satellite began to operate in July/2002) might not be enough to assess the effect of climate change on wildland fire occurrence.

The uptrend in the wildland fire incidence in Chile over the years evaluated in this study can be justified by the increment in areas planted with flammable species; by the rejection of these landscape modifications by local communities that target these plantations in arson attacks; and, by the adoption of forest management practices that results in the accumulation of a high fuel load (ÚBEDA; SARRICOLEA, 2016). No studies were found that comment on the increase wildland fire occurrence in Peru over the last years. The rise of the 
deforestation rate in the Peruvian Amazon Forest from 1999 to 2013 as appointed by Alarcón et al. (2016) could be one of the factors.

Regarding the seasonal changes in the wildland fire occurrence in South America, the results found in this study are in agreement with the literature. According Bella et al. (2006) and Soares and Batista (2007) the fire season in Brazil lasts from July to December, with the peak in the months of August and September. RodriguezMontellano (2013) also states that August and September are the months with the highest wildland fire occurrence in Bolivia. In Paraguay and Peru the highest occurrence goes from June to November (FAO, 2007; ANTUNES; ESQUERDO, 2009).

In Argentina, as in Brazil, the wildland fire season varies among different regions due to their large size. In Argentina southern territories where the rainy season occurs in winter, the wildfire season starts in late spring and last until early summer. In northern states and in Uruguay, fires tend to occur in autumn and winter (GOLDAMMER, 2001).

The dry season in Chile lasts from November to April and the wildfire season occurs from October to April. In Venezuela, the fire season is from December to April and wildfires occurs mostly in the eastern portion of the country where forests are being cut down to give place to agriculture (GOLDAMMER, 2001; FAO, 2007).

In French Guiana, Guyana and Suriname there is little published information about wildland fire occurrence. These countries have a short dry period in March and a long dry period from August to November with severity of dryness varying from year to year (BONAL et al., 2008). According the same author, some long dry periods remain mild with 50-100 $\mathrm{mm}$ precipitation each month, whereas some dry periods are severe with less them $50 \mathrm{~mm}$ rainfall in 4 months. In Equator wildland fires occur mainly in autumn and winter, while in Colombia mainly from January to May (FAO, 2007).

\section{CONCLUSION}

- In general, the number of wildland fires detected by AQUA satellite, using the "Collection 5" detection algorithm, had a small but not significant decrease over the last 15 years, a curious result since there is an expectation of growth in fire activity at global scale due to the global warming. Significant trend was only found in Peru and Chile, in both cases indicating an uptrend. These results are probably linked with the increase in the deforestation rate and on land change use in both countries.

- Despite the AQUA has being used as reference satellite by the INPE, data from others satellites should be analyzed in order to confirm the trends and annual changes in the wildland fire occurrence found in this study.

- The description of the months with higher fire activity within all South America countries is important data that can be used in the development of public policies focused in the reduction of wildfire events, as well as, subsidize programs of biodiversity management and conservation.

- Future studies that address the differences in the wildland fire occurrence in different regions and states of each country, especially in those with large territorial extension, are recommended in order to obtain more accurate data at a higher spatial resolution. Also, data from the next years need to continue being evaluated to confirm the trends observed in this study.

\section{ACKNOWLEDGEMENTS}

CNPq and FAPITEC/SE for the scholarship fund awarded to the author.

\section{REFERENCES}

ALARCÓN, G.; DÍAZ, J.; VELA, M.; GARCÍA, M.; GUTIÉRREZ, J. Deforestación en el sureste de la amazonia del Perú entre los años 1999-2013; caso Regional de Madre de Dios (Puerto Maldonado-Inambari). Revista Investigaciones Altoandinas, Puno, v. 18, n. 3, p. 319-330, 2016.

ANTUNES J. F. G.; ESQUERDO, J. C. D. M. Mapeamento do risco de incêndio na bacia do alto Paraguai utilizando dados AVHRR-NOAA. Geografia, Rio Claro, v. 34, n. especial, p. 783-794, 2009.

BATISTA, A. C. Detecção de incêndios florestais por satélite. Floresta, Curitiba v. 34, n. 2, p. 237-241, 2004.

BELlA, C. M.; JOBBÁGY, E. G.; PARUELO, J. M.; PINNOCK, S. Continental fire density patterns in South America. Global Ecology and Biogeography, [S.1.], v. 15, n. 2, p. 192-199, 2006.

BONAL, D.; BOSC, A.; PONTON, S.; GORET, J. Y.; BURBAN, B.; GROSS, P.; GUEHL, J. Impact of severe dry season on net ecosystem exchange in the Neotropical rainforest of French Guiana. Global Change Biology, [S.1.], v. 14, n. 8, p. 1917-1933, 2008. 
FLANNIGAN, M.; CANTIN, A. S.; DE GROOT, W. J.; WOTTON, M.; NEWBERY, A.; GOWMAN, L. M. Global wildland fire season severity in the 21st century. Forest Ecology and Management, Amsterdam, v. 294, p. 54-61, 2013.

FAO - FOOD AND AGRICULTURE ORGANIZATION OF THE UNITED NATIONS. Fire management global assessment 2006: a thematic study prepared in the framework of the global forest resources assessment, Roma: F.A.O., 2007.

GIGLIO, L.; SCHROEDER, W.; JUSTICE, C. O. The collection 6 MODIS active fire detection algorithm and fire products. Remote Sensing of Environment, [S.1.], v. 178, p. 31-41, 2016.

GIRI, C.; LONG. J. Land cover characterization and mapping of South America for the year 2010 using Landsat 30 m satellite data. Remote Sensing, Basel, v. 6, n. 10, p. 9494-9510, 2014.

GOLDAMMER, J. G. Global forest fire assessment 1990-2000. Rome: The Forest Resources Assessment Programme, 2001.

HANSEN, J.; RUEDY, R.; SATO, M.; LO, K. Global surface temperature change. Reviews of Geophysics, [S.1.], V. 48 , n. 4, p. 1-29, 2010.

INPE - INSTITUTO NACIONAL DE PESQUISAS ESPACIAIS. Portal do Monitoramento de Queimadas e Incêndios. Available: http://www.inpe.br/queimadas. Accessed in: 02 March 2018.

JOLLY, W. M.; COCHRANE, M. A.; FREEBORN, P. H.; HOLDEN, Z. A.; BROWN, T. J.; WILLIAMSON, G. J.; BOWMAN, D. M. Climate-induced variations in global wildfire danger from 1979 to 2013. Nature communications, [S.1.], v.6:7537, p. 1-11, 2015.

LIU, Y.; STANTURF, J.; GOODRICK, S. Trends in global wildfire potential in a changing climate. Forest ecology and management, Amsterdam, v. 259, n. 4, p. 685-697, 2010.

MENDONÇA, F.; DANNI-OLIVEIRA, I. M. Climatologia: noções básicas e climas do Brasil. São Paulo: Oficina de textos, 2017.

NOLASCO, M. I. M.; SANHUEZA, P. I. Wildfires in South America. Crisis response, Dorking, v. 6, n. 1, p. 5657, 2011.

RODRIGUEZ-MONTELLANO A. M. Dinámica de Incendios forestales y quemas en Bolivia. Santa Cruz, Bolivia: Fundación Amigos de la Naturaleza. 2013.

SOARES, R. V.; BATISTA, A. C. Incêndios Florestais: controle, efeitos e uso do fogo. Curitiba: UFPR, 2007. $250 \mathrm{p}$.

PEREIRA, A. A.; PEREIRA, J. A. A.; MORELli, F.; BARROS, D. A. Validação de focos de calor utilizados no monitoramento orbital de queimadas por meio de imagens TM. Cerne, Lavras, v. 18, n. 2, p. 335-343, 2012.

ÚBEDA, X.; SARRICOLEA, P. Wildfires in Chile: A review. Global and Planetary Change, [S.1.], v. 146, p. 152-161, 2016.

WANG, S.; MIAO, L. L.; PENG, G. An improved algorithm for forest fire detection using HJ data. Procedia Environmental Sciences, [S.1.], v. 13, p. 140-150, 2012.

WHITE, B. L. A. Spatiotemporal variation in fire occurrence in the state of Amazonas, Brazil, between 2003 and 2016. Acta Amazonica, Manaus, v. 48, n. 4, p. 359-368, 2018.

WHITE, B. L. A.; RIBEIRO, A. S.; WHITE, L. A. S.; RIBEIRO, G. T. Caracterização do material combustível superficial no Parque Nacional Serra de Itabaiana-Sergipe, Brasil. Ciência Florestal, Santa Maria, v. 24, n. 3, p. 699-706, 2014.

WHITE, B.L.A.; SILVA, M.F.A. Variações microclimáticas e perigo de ocorrência de incêndios florestais em fragmento de Mata Atlântica no município de São Cristóvão, Sergipe. NATIVA, Sinop, v. 6, n. especial, p. 729736, 2018.

WHITE, B. L. A.; WHITE, L. A. S. Queimadas e incêndios florestais no estado de Sergipe, Brasil, entre 1999 e 2015. Floresta, Curitiba, v. 46, n. 4, p. 561-570, 2016. 